\title{
The Protection of Mining Area in the time of Armed Conflict
}

\author{
Fransiska Ayulisty a Susanto \\ Faculty of Law \\ Universitas Brawijaya \\ Malang, Indonesia \\ fransiska.s@ub.ac.id
}

\author{
Herman Suryokumoro \\ Faculty of Law \\ Universitas Brawijaya \\ Malang, Indonesia \\ hermans-fh@ub.ac.id
}

\begin{abstract}
This paper offers the analysis of the Protection of Mining area in the time of armed conflict under the perspective of International law, especially international humanitarian law. Some argue that mining area is a protected area under the International humanitarian law. However, mining is one of the reasons that could lead to conflict, and one of the areas that the enemy plans to take over. In the end, this paper will also investigate whether the mining area haas nexus to the armed conflict, and endeavors to assess how international law and international humanitarian law protect the mining area.
\end{abstract}

Keywords-mining, armed conflict $[1]^{1}$, international humanitarian law, international law

\section{INTRODUCTION}

The discovery of natural resources in some area such as gold, oil, diamonds and other valuable natural resources in a country does not always give great improvement to the state development, but it could lead to socio-economic and political instability problem as well. In several cases, a wealth of natural resources in the state has even "triggered or fueled armed conflict"[2]", such as in Liberia, Sierra Leone, Cambodia and another state.

Mostly the natural resource is used to finance the armed conflict, sometimes the armed groups take over the mining area aiming to gain some profits. Since the global demand for natural resources keeps growing, the armed conflict over the natural resources will be endless.

The exploitation of natural resources by the armed conflict parties gives big impact not only to the civilians in the country but also could lead to the serious collateral damage to the environment. The civilians in the armed conflict not only face the threat of death, but they also in some case serve as slaves in the mining industry. The "blood diamond" in Angola and the child labor in Democratic Republic of Congo is one of examples [3]. In addition, the ISIS attack in Oil field in the Nineveh and around Mosul Iraq brings big loss to the Iraq economic, and the

\footnotetext{
According to Uppsala Conflict Data Program (UCDP), an armed conflict is "a contested incompatibility which concerns government and/or territory where the use of armed force between two parties, of which concerns government and/or territory where the use of armed force between two parties, of which at least one is the government of a state, results in at least 25 battle-related deat hs in one calendar years.
}

environment surrounding the oil field [4]. In some other cases, plundering and pillaging are becoming serious problem in mining areas. An armed group plunders and pillages the natural resources to sell it to buyers to earn some money [5].

Considering the fact above, the natural resource conflict could lead to armed conflict in some aspects. It is true that not all conflicts are caused by what arises from natural resources, but it does not mean that there is no nexus between both, in which this connection raises some questions: Is there a clear nexus between the armed conflict and natural resource conflict? What is the impact of those armed conflict on the society in surrounding area? And how does International Law or International Humanitarian Law protect the mining area from armed conflict?

This paper is aimed to answer the above questions by comparing some cases of International law treaties or conventions. This paper argues that the natural resource conflict could lead to the armed conflict, especially when the armed groups need the fund to do their action. Moreover, civilians in a conflict area clearly will face serious impact directly or indirectly caused by that conflict. In addition, the protection to the mining area of armed conflict is protected under protected object in International Humanitarian Law consequently; both of the armed parties shall not attack or use the mining area.

The first part of this paper will explain the nexus between the Natural resources and the armed conflict in a country or between countries. In addition, this part will also discuss the impact of the armed conflict regarding Natural resources to the society and environment surrounding the mining area. The last part will explain the protection of Natural resources in armed conflict under international humanitarian law. The conclusion discusses the protection of mining area of armed conflict and gives the suggestion to the government, the armed group, and private sectors to protect the mining area as part of a protected object during armed conflict.

\section{DISCUSSION}

\section{A. Natural Resources and Armed Conflict}

Since many years ago, the valuable natural resources have frequently been associated with conflict or used to finance the conflict, directly or indirectly. From the competition over to merchant capital and the imperialist wars 
over precious minerals and the natural resources increase the violence activities of many insurgent or rebel groups. Within the drastic drop of foreign fund for many governments and the insurgent or rebel group, the parties tend to find the new resources to fund their activities .

For the legal government, finding another resources like loan or trade will be easier than being involved in the activities of the rebel groups. Consequently, the insurgent shall find the illegal funding. The rebel group is hard to use legal activities thus they will try illegal action such as drug smuggling, timber and mineral illegal trading. In some cases, the rebel or insurgent group pillages to gain fund or even attack the mining area to get money from the corporation or the government operating the mining field.

In the history, the expedition of the European to find the natural resources and trade commodity has led to colonialis $\mathrm{m}$ around the world. Most of the time, the colonialists' acts violate the human rights of the native population. One of the examples of the violation of human rights was the colonization in the Congo by Belgian. The colonialism not only tried to robe the natural resources but also used the locals as slaves. The colonialism sparked an armed conflict between the colonialists and the locals in the colonized country.

The international armed conflict between the Democratic Republic of Congo and Uganda was also triggered by the natural resource conflict. Both of the countries agree to settle the case in front of International Court of Justice. The court decided that what Uganda did in Democratic Republic of Congo territory is part of the looting, plundering and exploitation of DRC's Natural resources [6].

In Non-international armed conflict, Philippine case, the New People Army (NPA) attacked mining companies and killed the company's officer in demand of ransom [7] In this case, the rebel group used Mining Corporation to be their source of their activities.

Some argue that, non-international armed conflicts are often associated with unsustainable patterns of resource exploitation, like in the conflict in Sierra Leone, Liberia, Angola, and Cote d'Ivoire. However, "Neither practical evidence nor extensive literatures have thus far been able to clarify how natural resources are inter-related with armed conflicts"[8]".

The parties that argue there is a link between the armed conflict and natural resource stated that mining can cause conflict over [9]: the control over the resources and mining area, conflict over the benefit sharing or the decision making related to mining area and the resources, and the conflict over social impact. Moreover, mining could: finance conflict, benefit from conflict, be targeted by conflict and be a supplier to those who profit from conflict [9]. Those entire links above could lead the conflict to armed conflict in a state. Consequently, there is close relation between armed conflict and mining

Moreover, Collier and Hoeffler argue that "primary commodities to be important factor in causing internal armed conflict, causing them to be an attractive target for "greedy rebels""'[10]. On the other hand, Ross stated "only oil affects armed conflict onset"[11]. Mary Kaldor and Terry Lynn also stated "oil as a natural resource is strongly associated with the onset of conflict [8], such as the rebellion in South Sudan etc.

In addition, Andrea Edorado Varisco argues "the presence or absence of natural resources in country seems only slightly inter-related with onset of an armed conflict"[8]". It is because the armed conflict does not happen in all countries that have abundance of natural resources such as Norway and Botswana seen as peaceful countries. In contrast, Haiti and Uganda with not many natural resources still face the armed conflict.

Consequently, the armed conflict in some countries cannot be solely caused by mining conflict, but there are probably some other triggering factors. Natural resources could be the main cause of the conflict among political, economic, social, and cultural factors that are also responsible for the armed conflicts .

\section{B. The Protection of Natural resources Mining Field in The Time of Armed Conflicts}

The protection of Mining field in the time of armed conflict could be divided into the protection of the Mining field itself from direct attack and protection of the Mining field from Pillaging or plundering. Both of the actions could lead to greater loss to the country. Under this part, type of protection received by mining areas under Humanitarian Law is presented.

\section{1) Protection from Direct Attack}

Before we determine the mining protection, we first shall classify the mining areas as protected objects under International Humanitarian Law. The protected objects under IHL are Civilian object, Medical Facility, cultural properties, natural environment, and works and installations containing dangerous forces. Things within those categorized Mining area fall under civilian object protection [3].

Under the Additional Protocol I to Geneva Convention article 52 (1) “... Civilian Objects are all objects which are not military object as defined in paragraph 2 " and under the Customary of International Humanitarian Law Rule Number 9 stated that "Civilian object are all objects that are not military object"[12]". Consequently, to determine whether an object is a civilian object, it could be observed whether the object is under the definition of military object. If the object does not fall under the definition of military object, it is regarded as civilian object. The military objects are all objects which "by nature 2 , location" ${ }^{3}$ purpose 4 e or use $e^{5}$ make an effective contribution to military action and whose total or partial destruction, capture or neutralization, in the circumstances ruling at the time, offer a definite military advantage [13]". In addition, in Non-international armed conflict, the protection of civilian object could fall under the International customary law. It is because there is no clear definition of civilian object in non-international armed

Under the Commentary on the Additional Protocol I , by nat ure make effective contribution is all object used by armed force, such as weapons, transport, or building used by the armed force.

3 Under the Commentary on the AdditionalProtocol I , "object location" where the location of the object could give military contribution such as bridge, etc

4 Under the Commentary on the Additional Protocol I , "purpose" refer to the intent of future use of the object

Under the Commentary on the Additional Protocol I , "use" refer to present function of theobject 
conflict regulation or in Additional Protocol II on the 1949 Geneva Convention relating to the Protection of victims of Non-international armed conflict.

The above definition implies that mining site is not a military object by nature, location, and purpose, nor is it something that effectively contributes to military action. Moreover, the damaged mining site does not lead to any military advantages.

Thus, it is clear that Mining area is categorized into a civilian object. Consequently, the mining field shall be protected all the time during armed conflict for the sake of the protection of the civilian object

The attack to the mining area could lead the violation to the article 52 (1) Additional Protocol I to Geneva Convention 1949 "Civilian object shall not be the object of attack or of reprisals", from that article it is clear that mining area could not be attacked under any circumstances unless the protection no longer exists. That argument is supported by the Customary International Hu manitarian Law Rule number 10 stating that "civilian objects are all protected against attack, unless and for such time they are military objects". However, like the other civilian objects, if the object no longer falls under the requirement of civilian object, the enemy could attack the mining area legally.

In addition, the mining area could also get protection under article 23 (g) of The Hague Regulation 1907 which prohibits the parties to destroy the enemy`s property. The mining field could be the parties' property, if the field is owned, controlled, or administered by the enemies [14]. Moreover, under the 53 Geneva Convention IV 1949, "Any destruction by the Occupying Power of real or personal property belonging individually or collectively to private persons, or to the State, or to other public authorities, or to social or co-operative organizations, is prohibited, except where such destruction is rendered absolutely necessary by military operations", however, the protection under this article only applied in the time of occupation.

Furthermore, under the Rome statute, the attack of the enemy property could fall under "the war crime of destroying or seizing the enemy's property" article 8 (2) (b) (xiii) for international armed conflict and article 8 (e) (xii) for non- international armed conflict. Moreover, the prohibition of "unjustified destruction"6 of enemy property is part of customary international law, consequently the prohibition is applicable in time of International armed conflict and non-international armed conflict. ${ }^{7}$ In the case of CDF case, the appeal chamber of the Sierra Leone expressly held the prohibition against destruction not justified by military necessity to be part of customary international law applicable in international armed conflict and noninternational armed conflict. ${ }^{8}$

The prohibition to attack the enemy's property covers huge range of the objects [3]. The word "enemy property" also covers the natural wealth and natural resource in the

6 If the military necessity and the proportional principle are not satisfied it is mean that the attack is unjustified under the Rome statute and International customary law.

The customary status is decides by the International Court of Justice (ICJ) in the advisory opinion on the construction of a wall in the Occupied Territory, 2004, para. 172

Prosecutor vs Moinina fofana and Allieu Kondewa, Appeal Chamber Judgement, para. 390. enemy's territory and the word "property of the adversary" [15]" refers to "any person who is considered to belong to another party" of the armed conflict. Even though the mining is owned by a private company, as long as the company is administered under the state or another party or even if the owner is the citizen of the other party, the mining field is still under protection.

The direct attack to the mining field is not permitted. The justification to attack the mining area is only possible if the mining area loses their protection status or in other words, the area becomes military objective or there is military necessity to attack the area.

\section{2) Protection from Pillage}

Pillage is regulated in The Hague Regulation of 1907 and also in World War Two under the categorized of War Crimes. Pillage itself means "theft during war, and is synonymous with other equally evocative terms such as looting, spoliation, and plunder[5]". The Pillage crimes are also codified in the court for World War Two such as Nuremberg Court under article 6 (b) Nuremberg Charter "plunder of public and private property is crime [5]" 9 . Moreover, it is also codified in the statute of International Criminal Tribunal for The Former Yugoslavia (ICTY), article 3 (e) "Plunder of public or private property" is part of violations of the laws or customs of war.

As stated above the private and public properties also include the natural resources. Consequently, the pillage action also covers the pillage in mining area.

However, as stated above pillage only applies in armed conflict or wartime. Thus, the evidence that the pillage is done in the time of armed conflict is crucial. The nexus between pillage and armed conflict is used to make differentiation between the pillage and theft or other crime under national regulation. It will also decide that the applicable law for this action is national law regarding war crime and also international instrument regarding International armed conflict and non-international armed conflict or war crimes or just penal code of the parties.

Under International humanitarian law, the prohibition of pillage is under article 28 and 47 of The Hague Regulation 1907. Both of the articles state that pillage is forbidden under all circu mstances. The article also stated that even though the pillage is not under the assault or by assault, the action also violates the regulation.

Moreover, after the World War Two, the International Humanitarian law under the Geneva Convention 1949 also declares that the pillage is prohibited. It is regulated under the Geneva Convention IV article 33 "pillage is prohibited". The development of armed conflict and pillage itself created the prohibition of pillage in non-international armed conflict too. It is regulated under Additional Protocol II on the Geneva Convention 1949 article 4(2)(g) which explicitly prohibits the pillage in non-international armed conflict.

This prohibition of pillage under international humanitarian law instruments above has already been widely accepted by states and has become customary international

The linguistic difference among Plunder (is used in English version of the charter) and pillage (is used in France version of the charter), is not a big deal because the court treated both of the terminology as the same action. Plunder and pillage are legally synonymous, para 11, p. 15 
law. The ICRC already includes it in its codification of customary international humanitarian law Rule no 52. Within the codification of the prohibition of pillage, consequently, in armed conflict (NIAC or IAC), all parties involved shall not pillage their enemy's property.

In addition, the probation of pillage is also regulated in the Statute of International Criminal Court under the War Crime categorized. ${ }^{10}$ The prohibition also covers the war crimes under international armed conflict and noninternational armed conflict.

In the jurisprudence, the prohibition of pillage is also clearly stated in so many cases. For example, in the Japanese Seizure of Oil Stock from Singapore, the judge declares "the seizure and subsequent exploitation by the Japanese armed forces of the oil resources of the appellants was economic plunder of private property in violation of the laws and customs of war[16][5]". In another case, ICC states that "for the crime of plunder [pillage] to be established, the appropriation of private or public property must be done without lawful basis or legal justification... According to the Hague Regulations, forcible contribution of money, requisition for the needs of the occupying army, and seizure of material obviously related to the conduct of military operations, though restricted, are lawful in principle."[17] In the ICC decision the prohibition of pillage only violates the international humanitarian law if there is no justification of that action. Another case under ICJ, the decision "... under an obligation, according to Article 43 of the Hague Regulation of 1907, to take all measures in its power to restore, and ensure, as far as possible, public order and safety in the occupied area, while respecting, unless absolutely prevented, the laws in force the DRC. This obligation comprised the duty to secure respect for the applicable rules of international human rights law and international humanitarian law, to protect the inhabitants of the occupied territory against acts of violence, and not to tolerate such violence by any third party". [18]". Within that decision ICJ declares that the occupying power has obligation to prevent natural resources exploitation, if the occupying power fails to qualify as pillage.

Finally, the prohibition of pillage is only applicable in the time of armed conflict and when there is no justification of the actions. Moreover, the prohibition of pillage has already turned into the custom of International law. Consequently, pillage is not allowed in any states despite the fact that the states are not members of Geneva Convention 1949 and they are embedded to the protocolor the Hague Regulation.

\section{CONCLUSION}

The mining conflict in some area could become the armed conflict. Even not all of the mining conflict will turn to the armed conflict there is still big chance that it turns into armed conflict. The protections of the mining area itself fall under the protection of civilian object and protection as enemy's property. It also receives protection from pillage. The mining area shall be protected all the time in time of international armed conflict or in non-international armed conflict, unless it loses the protection status, or the attack could be justified under Intemational Humanitarian Law. The protection of the mining area under International humanitarian law or customary international law is not only for the government mining field but also to the private fields.

Finally, it would be better to the state to prevent the mining conflict from developing to armed conflict. The state shall resolve the problem over the mining conflict as soon as possible, as effective as possible and shall look carefully what the local people need. The conflict over the min ing will not happen if the government makes proper regulation, administration, and provide fair treatment to the locals. Moreover, the monitoring system to the private mining company is also important to do. The government as the regulator shall give fair treatment to the mining company and local people in mining area.

\section{REFERENCES}

[1] D. of P. and C. Research, "Definitions." [Online]. Available: https://www.pcr.uu.se/research/ucdp/definitions/. [Accessed: 20-Jul2018].

[2] M. Renner, "the Anatomy of Resource War," Worldwatch Paperno 162, Jun-2002.

[3] Daniella Dam-deJong, International Law and Resource Plunder The Protection of Natural Resources during Armed Conflict, Yaerbook, of Internationall Environmental Law. Oxford: Oxford University Press, 2008.

[4] T svetana Paraskova, "Iraq Aims to Restart Oil Fields At tacked by ISIS," 2017. [Online]. Available: https://oilprice.com/Latest-EnergyNews/World-News/Iraq-Aims-To-Restart-Oil-Fields-Attacked-ByISIS.html. [Accessed: 19-Jul-2018].

[5] James G. Stewart, Corporate War Crimes. New York: Open Society Just ice Initiative Publication, 2011.

[6] Democratic Republic of Congo v. Uganda, ICJ Judgment. Democratic Republic of Congo v. Uganda.

[7] R. D. J. William N. Holden, Mining amid armed conflict: Nonferrous Metals Mining in The Philippines. Canadian Geographer, 2007.

[8] A. E. Varisco, “A Study on The Inter-Relation Between Armed Conflict and Natural resources and it Implications for Conflict Resolution and Peace building," J. Peace, Confl. Dev., no. 15, 2010.

[9] J. Switzer, "Discussion Paper for The July 112001 Expert Workshop on Armed Conflict and Natural Resources: The Case of Mineral Sector," 2001.

[10] Terje Mikal Espedal, The Relationship between Natural resources and Armed Conflict onset: "It's complicated". Department of Comparative Politic, University of Bregen, 2012.

[11] M. Ross, "What do we know about Natural resources and Civil War?,"J. Peace Res., vol. 41, no. 3, p. 337.

[12] I. C. of the R. Cross, Customary of International Humanitarian Law codified.

[13] Article 52 (2) the Additional Protocol I of Geneva Convention. 1949.

[14] Dist ein Y., "Booty in Warefare, in R. Wolfrum, ed.," in Max Planack Encyclopedia of Public International Law, 3AD, p. 7.

[15] A. Zimmerman, "O. Triffterer, ed." in Comentary on the Rome Statute of the International Criminal Court : Observer 'Notes, Article by Article, 1999, p. 8.

[16] N.V. De BataafschePetroleum Maatschappij and Others v. The War Damage Commission, "Singapore Law Reports (1956)."

[17] P. v. Martić, Case No. IT-95-11-T, Judgment, ICC. 2007.

[18] I. Judgment, Armed Activities Case (Democratic Republic of Congo vs Uganda). 